ournal for ImmunoTherapy of Cancer

\title{
Oxazaphosphorines combined with immune checkpoint blockers: dose- dependent tuning between immune and cytotoxic effects
}

\author{
Julia Delahousse (D) , ${ }^{1,2}$ Charles Skarbek, ${ }^{2}$ Mélanie Desbois, ${ }^{3}$ Jean-Luc Perfettini, ${ }^{1}$ \\ Nathalie Chaput, ${ }^{3,4,5}$ Angelo Paci ${ }^{1,5,6}$
}

\begin{abstract}
Background 0xazaphosphorines (cyclophosphamide (CPA), ifosfamide (IFO)) are major alkylating agents of polychemotherapy protocols but limiting their toxicity and increasing their efficacy could be of major interest. Oxazaphosphorines are prodrugs that require an activation by cytochrome P450 (CYP). CPA is mainly metabolized ( $>80 \%$ ) to phosphoramide mustard while only $10 \%-50 \%$ of IF0 is transformed in the alkylating entity, isophosphoramide mustard and $50 \%-90 \%$ of IF0 release chloroacetaldehyde, a nephrotoxic and neurotoxic metabolite. Geranyloxy-IFO (G-IFO) was reported as a preactivated IFO to circumvent the toxic pathway giving directly the isophosphoramide mustard without CYP metabolization. The similarity in structure of CPA and IFO and the similarity in metabolic balance of CPA and G-IFO have led us to explore immunomodulatory effect of these components in mice and to investigate the combination of these oxazaphosphorines with immune checkpoint blockers (ICB).
\end{abstract}

Methods The investigation of the immunomodulatory properties of IF0 and G-IFO compared with CPA has been conducted through immune cell phenotyping by flow cytometry and analysis of the cytokine profile of $T$ cells after ex-vivo restimulation. T cell-mediated antitumor efficacy was confirmed in $\mathrm{CD}^{+}$and $\mathrm{CD} 8^{+} \mathrm{T}$ cell-depleted mice. A combination of oxazaphosphorines with an anti-programmed cell death 1 (PD-1) antibody has been studied in MCA205 tumor-bearing mice.

Results Studies on a MCA205 mouse model have demonstrated a dose-dependent effect of IFO and G-IF0 on $\mathrm{T}$ cell immunity. These components in particular favored Th1 polarization when used at low dose (150 and eq. 100 $\mathrm{mg} / \mathrm{kg}$, respectively). Antitumor activity at low dose was abolished in mice depleted in $\mathrm{CD}^{+}$and $\mathrm{CD}^{+} \mathrm{T}$ cells. GIFO at low dose (eq. $100 \mathrm{mg} / \mathrm{kg}$ ) in combination with antiPD-1 antidody showed high synergistic antitumor efficacy compared with IF0.

Conclusion 0xazaphosphorines are characterized by a dual mechanism of antitumor action; low-dose schedules should be preferred in combination with ICB, and dose escalation was found to have better utility in polychemotherapy protocols where a conventional direct cytotoxic anticancer effect is needed. G-IF0, the novel oxazaphosphorine drug, has shown a better metabolic index compared with IFO as its metabolization gives mainly the alkylating mustard as CPA (and not IFO) and a best potential in combination with ICB.

\section{INTRODUCTION}

Oxazaphosphorines (Oxaza; that is, cyclophosphamide (CPA), ifosfamide (IFO)) are antineoplasic agents widely used to treat various cancers from soft-tissue tumors to lymphomas and are still the corner stone of several polychemotherapy protocols. They are major alkylating agents of polychemotherapy protocols but limiting their toxicity and increasing their efficacy could be of major interest. For IFO, dose regimens range from 1 to $12 \mathrm{~g} / \mathrm{m}^{2} /$ day in humans ${ }^{12}$ and 200 to $300 \mathrm{mg} / \mathrm{kg}$ in tumor-bearing mice ${ }^{3}$ when used as cytotoxic agent; for CPA dose range from 200 to $1000 \mathrm{mg} / \mathrm{m}^{2} /$ day in humans ${ }^{4-6}$ and from 100 to $250 \mathrm{mg} / \mathrm{kg}$ in tumor-bearing mice. ${ }^{7-9}$ IFO is an isomeric form of CPA and differs chemically from CPA in the localization of one of the chloroethyl groups leading to a different metabolization. Oxaza are prodrugs that require a metabolic activation by a specific liver cytochrome P450 (CYP). CPA is mainly metabolized by CYP2B6 leading to 4-HO-CPA, the key intermediate for alkylating mustard which reacts with DNA. The bioactivation of IFO by CYP3A4 produces 4-hydroxy derivative (4-HO-IFO), a key intermediate for isophosphoramide mustard release displaying cytotoxicity by DNA crosslinks. However, only $10 \%-50 \%$ of IFO is transformed into this key entity, and $50 \%-90 \%$ of IFO releases chloroacetaldehyde (CAA), a nephrotoxic and neurotoxic metabolite. ${ }^{10} 11$ These toxicities are increased in a high-dose setting; indeed, there is a dose-response relationship for IFO, that is, the higher the dose, the higher the IFO plasma exposure. ${ }^{12}$ Several high-dose IFO protocols (HD IFO) were studied. Le Cesne $e t$ $a l$ have studied efficacy and safety profile of 


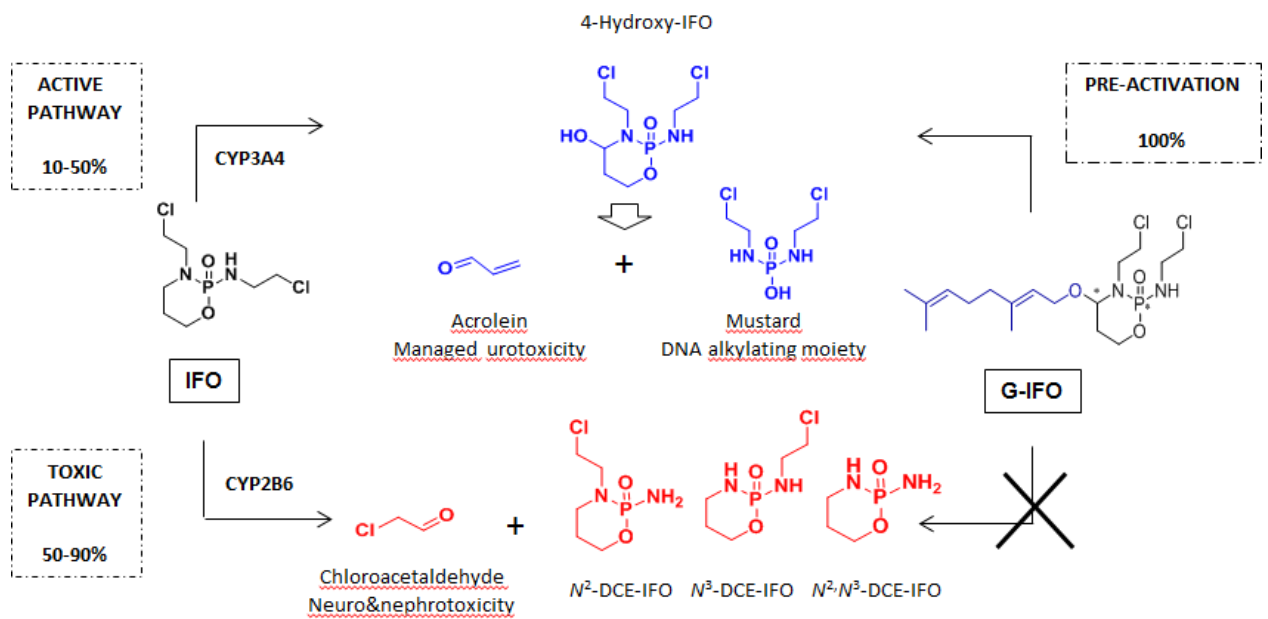

Figure 1 Preactivation of ifosfamide (IFO) to bypass the toxic pathway. Metabolism of IFO and geranyloxy-IFO (G-IFO) leading to the intermediate metabolite 4-hydroxy-IFO and others metabolites including toxic metabolite (chloroacetaldehyde).

HD IFO administered as a rescue medication (cumulative dose of $12 \mathrm{~g} / \mathrm{m}^{2}$ ) in patients with advanced refractory soft-tissue sarcomas which have not responded at standard doses of IFO. This study has demonstrated the efficacy (20 patients out of 36 showed partial or stable disease response), but with major toxicities. ${ }^{13}$ In pediatrics, the incidence of toxicities is high mostly in HD protocols. ${ }^{14}$ A clinical study in children with osteosarcoma receiving after HD IFO (cumulative dose of $14000 \mathrm{mg} / \mathrm{m}^{2}$ ) has shown an increase of $30 \%$ of progression-free survival, but with severe nephrotoxicity in a quarter of patients. ${ }^{15}$ The need to improve the IFO therapeutic index is an important clinical issue. Preactivated oxazaphosphorines (X-Oxaza) based on the link to terpene chains have been designed in order to bypass the metabolic pathways. ${ }^{16}$ As shown in figure 1, geranyloxy-IFO (G-IFO) leads to release 4-HO-IFO without releasing CAA. Skarbek et $a l^{17}$ have shown the cytotoxicity of G-IFO on a large panel of tumor models in vitro, validating the proof of concept of preactivation. As CPA and G-IFO give high levels $(66 \%-80 \%)$ of the alkylating entity compared with IFO (10\%-50\%), and CPA is known for its immunomodulatory properties, we therefore decided to explore the immune properties of IFO and G-IFO compared with CPA.

Tumor microenvironment plays an important role in tumor development. Indeed, microenvironment cells such as endothelial cells and stroma, immune cells may contribute to both tumor progression or tumor regression. ${ }^{18}$ Tumor cells may also provide mediators of immune escape through the secretion of immunosuppressive factors such as transforming growth factorbeta and through the expression of ligands for immune checkpoints establishing immune tolerance. Targeting the tumor cell environment seems to be a promising strategy to increase the efficiency of conventional chemotherapeutic agents. Immune checkpoint blockers (ICB) such as antiprogrammed cell death 1 (PD-1), antiprogrammed cell death ligand 1 (PD-L1) and anti-cytotoxic T-lymphocyte-associated protein 4 (CTLA-4) monoclonal antibodies (mAbs) have also proved their efficacy in many tumors such as melanoma ${ }^{19}$ and non-small-cell lung cancer treatment. ${ }^{20}$ Today, the combination of immunotherapy and conventional cancer therapy provides new and innovative antitumor strategies. ${ }^{21} 22$

Conventional antitumor chemotherapy is described as a direct cytotoxic agent used for targeting the DNA integrity (alkylating agents), the DNA and RNA synthesis (antimetabolites and cytotoxic antibiotics), the DNA replication (topoisomerase inhibitors) or cytosolic compounds (antimicrotubule agents). In addition to this direct cytotoxicity, several studies also revealed that conventional antitumor chemotherapies could modulate antitumor immune response. ${ }^{22}$ Indeed, some conventional chemotherapies can stimulate the immune system by depleting regulatory $\mathrm{T}$ cells (Treg), by subverting immunosuppressive mechanisms or exerting immunostimulatory activities. ${ }^{23} \mathrm{CPA}$ has a direct cytotoxicity through DNA binding at conventional doses and an indirect antitumor effect at low dose through the activation of antitumor immunity. Many reports have demonstrated the immunomodulatory effects of CPA through different mechanisms such as Treg cell depletion or inactivation, ${ }^{24-29}$ the polarization of $\mathrm{T}$ cells toward Th1 and Th1 $17{ }^{30}$ the modulation of myeloid cells toward inflammatory cells. ${ }^{31}$ More recently, it has been suggested that induction of pathogenic Th17 cells after CPA treatment was the consequence of the modulation of intestinal microbiota composition in tumor-bearing mice. ${ }^{32}$ Studies have described the enhancement of antitumor efficacy for CPA combined with immunotherapy through induction of immunogenic tumor death. ${ }^{33} 34$ Moreover, clinical studies have suggested that low myelosuppression in IFO-treated patients may have advantages over CPA in combination therapy ${ }^{35-37}$ Very few publications have focused on with the influence of IFO on the immune system compared with CPA and most in vitro studies have reported a negative impact of IFO on immunity. Lind $e t a l^{38}$ showed that IFO and its metabolites (4-HO-IFO and CAA) decrease the intracellular-glutathione (GSH) amount in the lymphocytes of patients treated with IFO 
at $5 \mathrm{~g} / \mathrm{m}^{2}$. GSH is the major intracellular thiol reductant that plays a protective role against oxidative injury; thus, GSH decrease affects survival, proliferation and functions of lymphocytes. Issels $e t a l^{39}$ confirmed that IFO could diminish GSH in lymphocyte in vitro and Multhoff et $a t^{40}$ showed that IFO could decrease the cytotoxic activity of $\mathrm{T}$ cells. More recently, Kuppner $e t a t^{11}$ suggested that IFO could decrease IFN $\gamma$ production by $\mathrm{T}$ cells. These in vitro results seem in contradiction with data accumulated with CPA demonstrating an activation of $\mathrm{T}$ cell immunity. To our knowledge, no study to date has explored the immunomodulatory activity of IFO in vivo.

In the current study, we studied the capacity of IFO and G-IFO to modulate $\mathrm{T}$ cell polarization in tumor-bearing mice. We demonstrated that low-dose IFO and G-IFO (1) favor Th1 polarization, (2) induce the T cell-dependent antitumor effect in mice and (3) increase the efficacy of anti-PD-1 antibodies in tumor-bearing mice. At high dose, IFO and G-IFO induced lymphopenia and synergy with anti-PD-1 was completely lost. Altogether, low doses of IFO and G-IFO could represent an efficient strategy to increase the response rate in patients treated with immune checkpoint inhibitors.

\section{MATERIALS AND METHODS}

\section{Chemical agents and reagents}

CPA (Endoxan; Baxter) and IFO (Holoxan; Baxter) were provided by Gustave Roussy Cancer Campus Grand Paris. Preactivated analog of IFO, G-IFO, was synthesized with $99 \%$ purity as previously described in. ${ }^{16}$ For in vivo studies, CPA and IFO were dissolved in $\mathrm{NaCl} 0.9 \%$ or DMSO/Tween $80 / \mathrm{NaCl} 0.9 \%$ (5/5/90, v/v/v). G-IFO was dissolved in DMSO/Tween $80 / \mathrm{NaCl} 0.9 \%$ (5/5/90, $\mathrm{v} / \mathrm{v} / \mathrm{v}$ ). Monoclonal anti-CD4 (GK1.5), anti-CD8 $\alpha$ (53-6.72), anti-PD-1 (RMP1-14) and their isotype control rIgG2a (2A3) for in vivo experiments were purchased from BioXCell (West Lebanon, New Hampshire, USA) and dissolved in phosphate-buffered saline. mAbs used for flow cytometry and immunohistochemistry analysis are described in table 1.

\section{Mice and tumor cell line}

7-8 weeks old female C57BL/6 mice (mean body weight, $20 \mathrm{~g}$ ) were purchased from Harlan Laboratories (Gannat,
France). Animals were used in pathogen-free conditions. MCA205 fibrosarcoma tumor cell line (syngenic from $\mathrm{C} 57 \mathrm{Bl} / 6$ mice) was kindly provided by Dr Yamazaki Takahiro (INSERM U1015, Gustave Roussy, Villejuif, France). They were harvested at $37^{\circ} \mathrm{C}$ under $5 \% \mathrm{CO}_{2}$ in Gibco RPMI 1640 medium (Paisley, UK) supplemented with $10 \%$ Fetal Bovine Serum (Paisley, UK) and 2 мм L-glutamine (Invitrogen, USA). All animal experiments were carried out in compliance with French and European laws and regulations and by the CEEA26 Ethics committee and the French national ministry of education, higher education and research and carried out under conditions established by the European Community (Directive 2010/63/2015-038).

\section{Tumor model and tumor inoculation in mice}

A total of 188 mice have been inoculated subcutaneously with $8.10^{5}$ tumor cells in the right flank of $\mathrm{C} 57 \mathrm{Bl} / 6$ mice on D0. After 7-9 days, the mean tumor volume (SD) was $167 \pm 96 \mathrm{~mm}^{3}$ (median volume: $143 \mathrm{~mm}^{3}\left(48-559 \mathrm{~mm}^{3}\right)$ ). $\left(\mathrm{V}\left(\mathrm{mm}^{3}\right)=\right.$ width $^{2}\left(\mathrm{~mm}^{2}\right) \times$ length $\left.(\mathrm{mm}) / 2\right)$. The intergroup heterogeneity was checked for equivalence in all our experiments. Mice received a single intraperitoneal (i.p.) injection of CPA at $100 \mathrm{mg} / \mathrm{kg}, \mathrm{IFO}$ at $100,150,200$ or $300 \mathrm{mg} / \mathrm{kg}$, vehicle or G-IFO at equimolar dose of IFO 50,100 or $150 \mathrm{mg} / \mathrm{kg}$.

For $\mathrm{T}$ cell depletion, mice received $200 \mu \mathrm{g} /$ mouse i.p. injections of anti-CD8 $\alpha$ (clone 53-6.72) and/or anti-CD4 (clone GK1.5) or their isotype control Rat IgG2a (clone 2A3) on Days (D) $-3, \mathrm{D} 0, \mathrm{D}+3$ then once a week, and IFO or control on D7. A combination treatment of chemotherapy (CPA, IFO, G-IFO) and anti-PD-1 mAbs was given to the mice. Based on laboratory experiences (a single injection of chemotherapy followed by three injections of anti-PD-1 spaced by 3-4 days) and various tumor growth kinetics in mice, the schedule was assessed as following: the mice received CPA or IFO on D7 then $250 \mu \mathrm{g} /$ mouse i.p. injections of anti-PD-1 mAbs (clone RMP1-14) or its isotype control Rat IgG2a (clone 2A3) on D9, D12 and D15, or the mice received G-IFO on D9 then $200 \mu \mathrm{g} /$ mouse i.p. injections of anti-PD-1 mAbs or IgG2a on D12, D15 and D19. Tumor volume was monitored three times a week by measuring the length and width using a caliper. In order to normalize tumor measurements for each day,

Table 1 Antibodies used for flow cytometry experiments

\begin{tabular}{lllll}
\hline Antigen & Species & Clone & Fluorochrome & Supplier \\
\hline CD45 & Mouse & $30-F 11$ & FITC & BD biosciences \\
CD3 $\varepsilon$ & Mouse & $145-2$ C11 & APC-Cy7 & BD biosciences \\
CD4 & Mouse & RM4-5 & PC7 & BD biosciences \\
CD8 $\alpha$ & Mouse & $53-6.7$ & APC-R700 & BD biosciences \\
FoxP3 & Mouse & FJK-16s & APC & eBiosciences \\
CD25 & Mouse & PC61 & PE & BD biosciences \\
CD19 & Mouse & 6D5 & BioLegend \\
\hline
\end{tabular}


$\mathrm{VT}_{\mathrm{Dx}}$ to $\mathrm{VT}_{\mathrm{Di}}\left(\mathrm{VT}_{\mathrm{Dx}} / \mathrm{VT}_{\mathrm{Di}}\right)$ ratio was calculated; $\mathrm{VT}_{\mathrm{Di}}$ corresponds to the tumor volume the day of treatment initiation and $\mathrm{VT}_{\mathrm{Dx}}$ corresponds to the tumor volume on each measurement day for each mouse.

\section{Flow cytometry analysis}

Female C57BL/6 mice of 7-8 weeks were randomly assigned to the different treatment groups. Six groups of mice were evaluated including an untreated control group which received the vehicle and 4-5 treated groups with IFO at the dose of 100, 150, 200 and $300 \mathrm{mg} / \mathrm{kg}$ and CPA at $100 \mathrm{mg} / \mathrm{kg}$. Both drugs were dissolved in a solution of $\mathrm{NaCl} 0.9 \%$.

We added groups treated with G-IFO at the equimolar dose of IFO 50,100 and $150 \mathrm{mg} / \mathrm{kg}$ and these were compared with the groups treated with CPA and IFO. Drugs were dissolved in a solution of DMSO/Tween 80 / $\mathrm{NaCl} 0.9 \%(5 / 5 / 90, \mathrm{v} / \mathrm{v} / \mathrm{v})$. The administrations were performed by a single i.p. injection with a volume of $20 \mathrm{~mL} / \mathrm{kg}$ or $10 \mathrm{~mL} / \mathrm{kg}$ when adding G-IFO groups. Seven days post treatment, the mice were sacrificed, spleens and tumors were collected. After lysis of red blood cells with ammonium chloride splenic viable cells were quantified using Vi-CELL XR (Beckman Coulter).

Briefly, tumor dissociation was carried out using a GentleMACS Dissociator after adding ADNase (260913, Millipore) and ligase (5401127001, Sigma) to weighed and cut tumors. Tumor cells were incubated for $40 \mathrm{~min}$ at $37^{\circ} \mathrm{C}$ under stirring and then quantified using Vi-CELL XR (Beckman Coulter). Before staining, Fc $\gamma$-receptors were blocked for $15 \mathrm{~min}$ at $4^{\circ} \mathrm{C}$ using anti-CD16/32 functional grade purified antibodies (eBioscience, Paris, France). Cells were incubated for $30 \mathrm{~min}$ at $4^{\circ} \mathrm{C}$ with antibodies for cell surface staining. For FoxP3 staining, cells were fixed and permeabilized after cell surface staining according to the FoxP3 kit protocol (eBioscience, Paris, France). Samples were analyzed using the 10-colors Gallios cytometer (Beckman Coulter, Villepinte, France). Analyses were performed using Kaluza software V.1.3 (Beckman Coulter). Two different panels were used to identify immune cells. First leucocytes were identified using FITC-conjugated antimouse CD45. T and B lymphocytes were identified using APC-Cy7-conjugated antimouse CD3e and BV421-conjugated antimouse $\mathrm{CD} 19$, respectively. $\mathrm{CD} 4^{+}$and $\mathrm{CD} 8^{+} \mathrm{T}$ cells were separated using PE-Cy7-conjugated antimouse CD4 and APC-R700conjugated antimouse $\mathrm{CD} 8$ a staining among CD3 positive cells, respectively. Treg cells were stained using APCconjugated antimouse FoxP3 staining among $\mathrm{CD}^{+} \mathrm{CD}^{+}$ $\mathrm{T}$ cells (table 1$)$.

\section{Cytokine assay}

A spleen cell suspension was prepared and $2.10^{5}$ cells per well were incubated in 96 well Nunc MaxiSorp plates (eBioscience) precoated with anti-CD3 $\varepsilon$ mAbs (clone 145-2 C11, $10 \mu \mathrm{g} / \mathrm{mL}$; eBioscience) and/or anti-CD28 mAbs (clone 37.57, $2 \mu \mathrm{g} / \mathrm{mL}$; BD Pharmingen). The supernatants were collected after 48 hours of incubation at $37^{\circ} \mathrm{C}$ under $5 \% \mathrm{CO}_{2}$ and the cytokine concentrations were quantified in the supernatant using a Bio-Plex Mouse Cytokine Standard 23-Plex, Group I Assay (bio $\mathrm{rad}, \mathrm{M} 60009 \mathrm{RDPD})$. The panel comprised the following cytokines and chemokines: eotaxin, granulocyte-colony stimulating factor, granulocyte-macrophage-colony stimulating factor (GM-CSF), interferon gamma (IFN $\gamma$ ), interleukin (IL)-1 $\alpha$ (IL-1 $\alpha$ ), IL-1 $\beta$, IL-2, IL-3, IL-4, IL-5, IL-6, IL-9, IL-10, IL-12p40, IL-12p70, IL-13, IL-17A, keratinocyte chemoattractant, macrophage chemotactic protein-1, macrophage inflammatory protein (MIP)1alpha (MIP-1 $\alpha$ ), MIP-1 $\beta$, regulated on activation normal $\mathrm{T}$ cell expressed and secreted and tumor necrosis factoralpha. Results were analyzed using Bio-Plex Manager Software V.6.1 (Bio-Rad Laboratories, Hercules, California, USA). The selection of cytokines and chemokines that were significantly regulated after IFO treatment in mice enabled us to to reduce the monitoring to IFNy, IL-17A and IL-6. These three cytokines were then quantified using mouse IL-17A ELISA Ready-SET-Go (eBiosciences), Mouse IFNy ELISA Set (BD Biosciences) and Mouse IL-6 ELISA Set (BD Biosciences).

\section{Statistical analysis}

Data were analyzed with Microsoft Excel (Microsoft Co.), Prism V.5.0 and V.8.0 software (GraphPad San Diego, California, USA). All results are expressed as mean $\pm \mathrm{SE}$ of mean or median with IQR. Statistically significant differences were analyzed using the non-parametric MannWhitney test or the non-parametric Kruskall-Wallis test to compare more than two independent groups. The two-way analysis of variance test was used to compare groups with two independent variables coupled to Geisser-Greenhouse for correction of violation of sphericity in repeated measures. No adjustment for multiple comparisons was made with small populations $(n \leq 6)$ because of the exploratory component of the analyses. A $\mathrm{p}$ value smaller than 0.05 was considered to be statistically significant. Significant $\mathrm{p}$ values were annotated as follows: $* \mathrm{p}<0.05, * * \mathrm{p}<0.01, * * * \mathrm{p}<0.001, * * * * \mathrm{p}<0.0001$.

\section{RESULTS \\ Low dose of IFO delays tumor growth through immunomodulatory effect}

The effect of escalating doses of IFO on antitumor response and immune response was explored. Its isomeric form, CPA, was used at $100 \mathrm{mg} / \mathrm{kg}$ since previous studies have demonstrated its immune-mediated antitumor response at this dose.

Antitumor activity of escalating single i.p. injections of IFO $(100,150,200$ and $300 \mathrm{mg} / \mathrm{kg})$ or of CPA $(100 \mathrm{mg} /$ $\mathrm{kg}$ ) in the immunocompetent MCA205-bearing C57Bl/6 mice was assessed. As shown in figure 2A (and online supplementary Figure S4A) and as expected, a significant reduction of the tumor growth was observed for CPA at $100 \mathrm{mg} / \mathrm{kg}$; for IFO, we observed a delay of tumor growth 
A

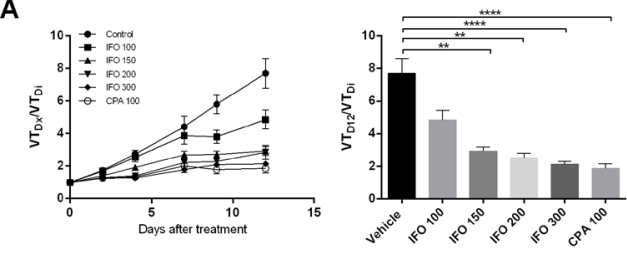

B
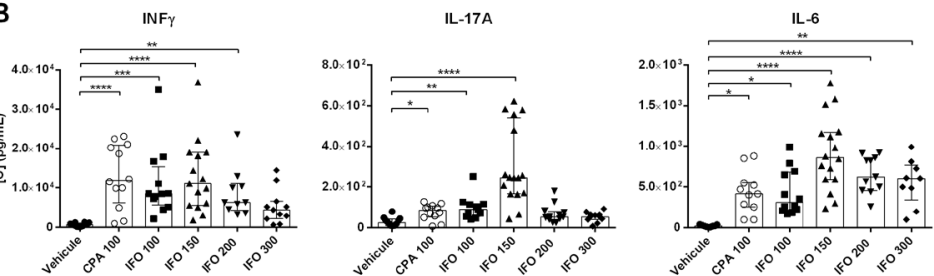

C
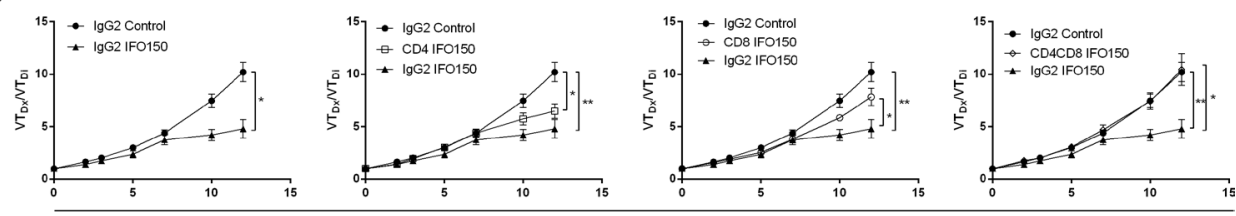

Figure 2 Low dose of ifosfamide (IFO) delays tumor growth in mice through immunomodulatory effect. MCA205 tumor-bearing mice were treated with a single intraperitoneal (i.p.) injection of IFO (100; 150; 200; $300 \mathrm{mg} / \mathrm{kg}$ ) or cyclophosphamide (CPA; $100 \mathrm{mg} / \mathrm{kg}$ ) or vehicle ( $\mathrm{NaCl} 0.9 \%$ ). (A) Tumor volume was measured every $2-3$ days, $\mathrm{VT}_{\mathrm{Di}}$ corresponds to the tumor volume on the day of treatment initiation and $\mathrm{VT}_{\mathrm{Dx}}$ correspond to the tumor volume. $\mathrm{VT}_{\mathrm{Dx}}$ to $\mathrm{VT}_{\mathrm{Di}}$ ratio $\left(\mathrm{VT}_{\mathrm{Dx}} \mathrm{NT}_{\mathrm{Di}}\right)$ is depicted from two pooled experiments ( $\mathrm{n}=8$ to 12 mice per group). (left) Kinetic tumor growth and (right) $\mathrm{VT}_{\mathrm{D} 12} \mathrm{NT}_{\mathrm{Di}}$ are depicted. Graphs depict the mean \pm SEM. Statistical analysis using two ways analysis of variance (ANOVA) test indicated significant differences at $95 \% \mathrm{Cl}$. *, $\mathrm{p}<0.05 ;{ }^{\star \star}, \mathrm{p}<0.01 ;{ }^{\star \star \star}, \mathrm{p}<0.001 ;{ }^{\star \star \star}, \mathrm{p}<0.0001$. (B) Seven days after treatment, mice were sacrificed and spleens were collected and incubated with anti-CD3 $\varepsilon$ for 48 hours at $37^{\circ} \mathrm{C}$. Supernatants were harvested and concentrations of (left panel) interferon $\gamma(\mathrm{IFN} \gamma$ ), (middle panel) interleukin (IL)-17A and (right panel) IL-6 were analyzed by ELISA. Graphs depict data from two pooled experiments (6-8 mice per experiment). Medians with IQR are shown. Statistical analysis using Kruskal-Wallis test indicated significant differences at $95 \% \mathrm{Cl} .{ }^{*}, \mathrm{p}<0.05 ;{ }^{* \star}, \mathrm{p}<0.01 ;{ }^{* \star *}, \mathrm{p}<0.001 ;{ }^{* \star *}, \mathrm{p}<0.0001$. (C) MCA205 tumor-bearing mice were depleted in $\mathrm{CD}^{+}$and/or CD8+ T cells, and treated with a single i.p. injection of IFO $150 \mathrm{mg} / \mathrm{kg}$; $\mathrm{VT}_{\mathrm{Dx}} \mathrm{NT}_{\mathrm{Di}}$ according treatment groups from pooled mice ( $n=6$ per group) is depicted. Graph depicts the mean \pm SEM. Statistical analysis using the two ways ANOVA test indicated significant differences at $95 \% \mathrm{Cl}$. No adjustment for multiple comparisons was made because of the exploratory component of the analyses. ${ }^{*}, p<0.05 ;{ }^{* *}, p<0.01 ;{ }^{* *}, p<0.001 ;{ }^{* * *}, p<0.0001$.

at low doses (100 and $150 \mathrm{mg} / \mathrm{kg}$ ) and higher doses (200 and $300 \mathrm{mg} / \mathrm{kg}$ ).

In a previous work, we have shown that CPA at $100 \mathrm{mg} /$ $\mathrm{kg}$ could increase the $\mathrm{T}$ cell receptor (TCR)-driven cytokine release in naive and tumor-bearing mice. ${ }^{35}$ We carried out similar experiments in mice treated with escalating doses of IFO in naive mice and in MCA205-bearing mice.

In naïve mice, IFN $\gamma$, IL-17A and IL-6 were significantly increased after treatments. As expected, the vehicle displayed weak cytokine secretions, in mice treated with CPA at $100 \mathrm{mg} / \mathrm{kg}$, TCR-driven IFN $\gamma$, IL-17A and IL-6 were significantly increased as previously published. Regarding the IFO groups (100, 150 and $200 \mathrm{mg} / \mathrm{kg})$, a significant increase of TCR-driven IFN $\gamma$, IL-17A and IL-6 was also observed after CD3c+CD28 stimulation (online supplementary Figure S1).

As for naive mice, we examined $\mathrm{T}$ cell polarization after TCR engagement in MCA205 tumor-bearing mice. The known cytotoxic dose of IFO, that is, $300 \mathrm{mg} / \mathrm{kg}^{3}$ was added to the experiment in tumor-bearing mice. As shown in figure 2B, IFO 200 and $300 \mathrm{mg} / \mathrm{kg}$ failed to induce IL-17A and IFN $\gamma$ TCR-driven cytokines, only TCRdriven IL-6 remained highly secreted (figure 2B). These results are reminiscent of the $\mathrm{T}$ cell counts diminution (online supplementary Figure S2) as well as decrease of $\mathrm{T}$ cell proportion (online supplementary Figure S3) observed at higher doses. For IFO at 100 and $150 \mathrm{mg} / \mathrm{kg}$ where no $\mathrm{T}$ cell counts decrease was observed in tumorbearing mice (online supplementary Figure S2), significant secretion of TCR-driven IL-17A, IFN $\gamma$ and IL-6 was detected after CD3e (figure 2B) and after CD28 costimulation (data not shown). Unexpectedly, IFO $150 \mathrm{mg}$ / $\mathrm{kg}$ induced more TCR-driven IL-17 and IL-6 than CPA $100 \mathrm{mg} / \mathrm{kg}$. IL-6 has been implicated in Th17 differentiation $^{37}$; thus, the higher IL- 6 in IFO at $150 \mathrm{mg} / \mathrm{kg}$ could explain the high Th17 differentiation compared with CPA.

A complementary study has been performed in order to confirm the $\mathrm{T}$ cell involvement in antitumor activity for IFO at low dose. MCA205-bearing mice were depleted in both $\mathrm{CD} 4^{+}$and $\mathrm{CD}^{+} \mathrm{T}$ cells, and treated with a single i.p. injection of IFO at $150 \mathrm{mg} / \mathrm{kg}$. As shown in figure 2C (and 
online supplementary Figure S4C), significant reduction of the tumor growth was observed for non-depleted mice; for $\mathrm{CD}^{+} \mathrm{T}$ cells and $\mathrm{CD} 8^{+} \mathrm{T}$ cells depleted mice, we observed a decrease of the antitumor effect. Finally, antitumor efficacy of IFO $150 \mathrm{mg} / \mathrm{kg}$ was completely abolished in mice depleted with both $\mathrm{CD} 4^{+}$and $\mathrm{CD} 8^{+} \mathrm{T}$ cells. Altogether these data indicated that at low dose of IFO $(150 \mathrm{mg} / \mathrm{kg})$, T cells are mandatory to observe an antitumor immune-mediated effect.

\section{Less toxic preactivated IFO (G-IF0) also reveals immunomodulatory properties}

Results on immune-mediated antitumor response of IFO at low dose led us to study immunomodulatory properties on the less toxic preactivated IFO derivative, G-IFO.

Pharmacokinetic study has shown that G-IFO could release higher quantity of HO-IFO than IFO. ${ }^{17}$ Consequently, we expected to have a delay in tumor growth at lower doses of G-IFO compared IFO. The dose of G-IFO is defined as the equivalent molar dose of IFO (eq. $\mathrm{X}$ $\mathrm{mg} / \mathrm{kg}$ ). For instance, $40 \mathrm{mg} / \mathrm{kg}$ of G-IFO is equivalent to $25 \mathrm{mg} / \mathrm{kg}$ of IFO as the molar masses are $419 \mathrm{~g} / \mathrm{mol}$ for G-IFO and $261 \mathrm{~g} / \mathrm{mol}$ for IFO. We assessed the antitumor activity of single i.p. injections of G-IFO at eq. $100 \mathrm{mg} /$ $\mathrm{kg}$ in the immune competent MCA205-bearing C57Bl/6. The dose of G-IFO at eq. $100 \mathrm{mg} / \mathrm{kg}$ did not show cytotoxicity on $\mathrm{T}$ cell populations in spleens (figure $3 \mathrm{~A}$ ) or in tumors (figure $3 \mathrm{~B}$ ) compared with higher dose of G-IFO (eq. $150 \mathrm{mg} / \mathrm{kg}$ ). As shown in figure 3D (and online supplementary Figure S4B), a significant delay of the tumor growth was observed for the three molecules with a lower tumor growth delay for G-IFO compared with CPA $100 \mathrm{mg} / \mathrm{kg}$. These primary data suggest that G-IFO is able to delay tumor growth even with a single low dose.

As for CPA and IFO 150, we investigated the TCRdriven cytokine release in MCA205-bearing mice for the escalating doses of G-IFO. As shown in figure 3C, G-IFO eq. $150 \mathrm{mg} / \mathrm{kg}$ induced high levels of IL-6 but poor secretion of IFN $\gamma$ whereas G-IFO eq. $100 \mathrm{mg} / \mathrm{kg}$ favored IFN $\gamma$
A

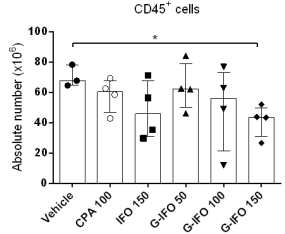

B

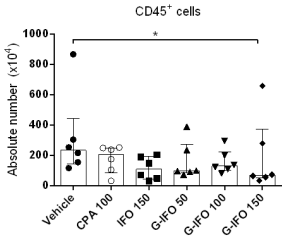

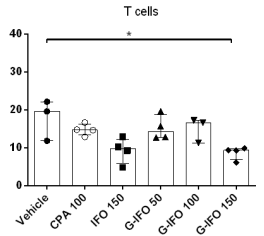
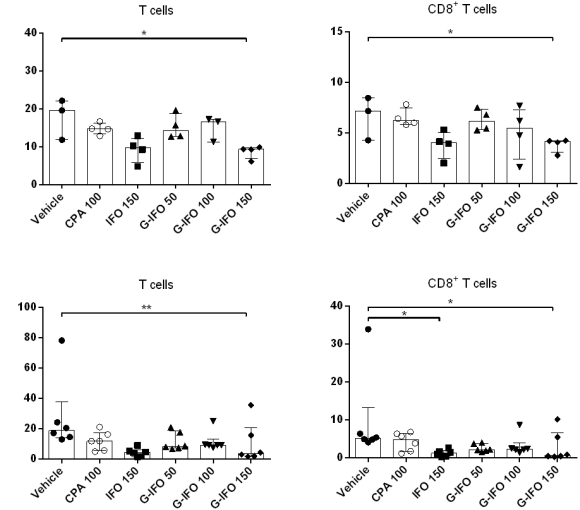
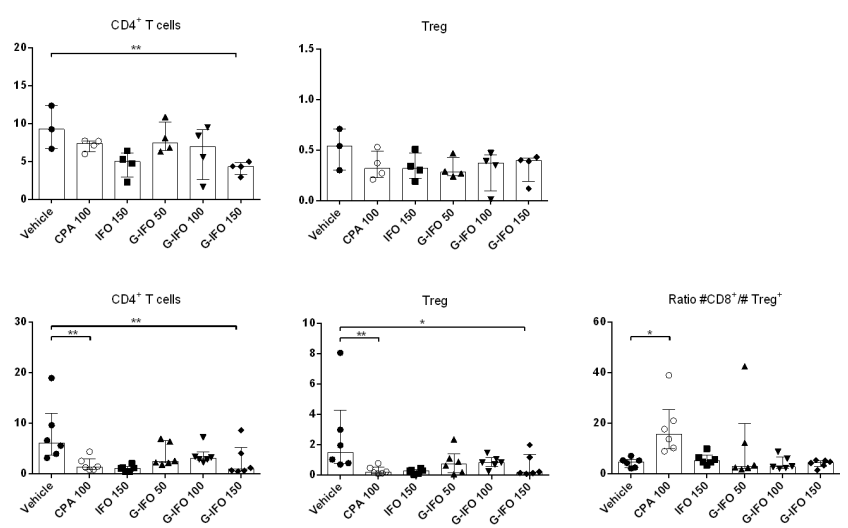

D
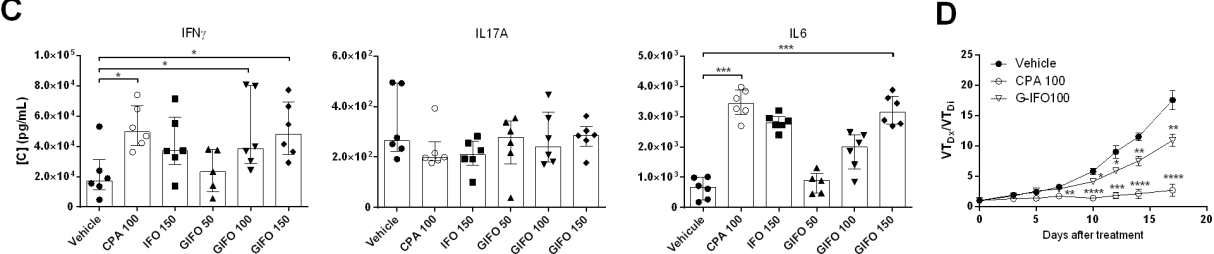

Figure 3 Low doses of geranyloxy-ifosfamide (G-IFO) promote T cell immunity and delay tumor growth in mice. MCA205 tumor-bearing mice were treated with a single i.p. injection of G-IFO (eq. $100 \mathrm{mg} / \mathrm{kg}$ ) or ifosfamide (IFO; 150 mg/kg) or cyclophosphamide (CPA; $100 \mathrm{mg} / \mathrm{kg}$ ) or vehicle (DMSO/Tween 80/ $\mathrm{NaCl} 0.9 \%(5 / 5 / 90, \mathrm{v} / \mathrm{v} / \mathrm{v})$ ). (A) Seven days later, mice were sacrificed and spleens were collected. Lymphocytes were detected in the spleen after mechanic dissociation using flow cytometry methods. Absolute number of splenocytes, T cells, CD8 ${ }^{+} \mathrm{T}$ cells, CD4 ${ }^{+} \mathrm{T}$ cells and Treg cells. Graphs depict data from one experiment ( $n=3-4$ mice/group). Median values with IQR are presented. (B) Seven days later, mice were sacrificed and tumors were collected. Lymphocytes were detected in the tumor after mechanical dissociation using flow cytometry methods. Absolute number of splenocytes, T cells, CD8 ${ }^{+} \mathrm{T}$ cells, CD4 ${ }^{+} \mathrm{T}$ cells, Treg cells and ratio CD8 ${ }^{+} \mathrm{T}$ cells/Treg. Graphs depict data from one experiment ( $n=6$ mice/group). Median values with IQR are presented. (C) Seven days after treatment, mice were sacrificed, and spleens were collected. Splenocytes were incubated with anti-CD3 $\varepsilon$ for 48 hours at $37^{\circ} \mathrm{C}$. Supernatants were harvested and concentrations of (left panel) interferon gamma (IFN $\gamma$ ), (middle panel) interleukin (IL)-17A and (right panel) IL-6 were analyzed by ELISA. Graphs depict data from one experiment ( $n=6$ mice/group). Medians with IQR are shown. (D) Tumor volume was measured every 2-3 days, $\mathrm{VT}_{\mathrm{Di}}$ corresponds to the tumor volume the day of treatment initiation and $\mathrm{VT}_{\mathrm{Dx}}$ correspond to the tumor volume. $\mathrm{VT}_{\mathrm{Dx}}$ to $\mathrm{VT}_{\mathrm{Di}}$ ratio $\left(\mathrm{VT}_{\mathrm{Dx}} / \mathrm{VT}_{\mathrm{Di}}\right)$ is depicted from one experiment ( $\left.\mathrm{n}=6 \mathrm{mice} / \mathrm{group}\right)$. Graph depicts mean \pm SEM. (A,B,C) Statistical analysis using Kruskal-Wallis test indicated significant differences at 95\% Cl. (D). Statistical analysis using the two ways analysis of variance test indicated significant differences at $95 \% \mathrm{Cl}$. (A, B, C, D) No adjustment for multiple comparisons was made because of the exploratory component of the analyses. ${ }^{*}, \mathrm{p}<0.05 ;{ }^{* \star}, \mathrm{p}<0.01 ;{ }^{\star \star \star}, \mathrm{p}<0.001 ;{ }^{\star \star \star \star}$, $\mathrm{p}<0.0001$. 
secretion, that is, Th1 polarization. No significant IL-17 secretion could be observed in these experiments with G-IFO.

Altogether, G-IFO at eq. $150 \mathrm{mg} / \mathrm{kg}$ was induced $\mathrm{T}$ cell depletion probably limiting Th1 accumulation while G-IFO eq. $100 \mathrm{mg} / \mathrm{kg}$ showed an antitumoral activity, did not affect the numbers of $\mathrm{T}$ cells and demonstrated an increase of IFN $\gamma$ and IL-6 secretions. Therefore, we decided to select G-IFO at eq. $100 \mathrm{mg} / \mathrm{kg}$ as the immunomodulatory dose.

\section{Synergy between anti-PD-1 antibody and (X-)0xaza}

As shown in previous studies ${ }^{4-44}$ and as shown in figure 4A-C, anti-PD-1 mAbs were not able to reduce tumor growth in the MCA205 tumor model.

No improvement of the antitumor efficacy could be observed with IFO at high dose $(300 \mathrm{mg} / \mathrm{kg})$ when associated to anti-PD-1 mAbs (figure 4). This observation was expected at this dose because of the non-specific lymphodepletion described previously (online supplementary Figure S2). Unexpectively, IFO at the immunomodulatory

A
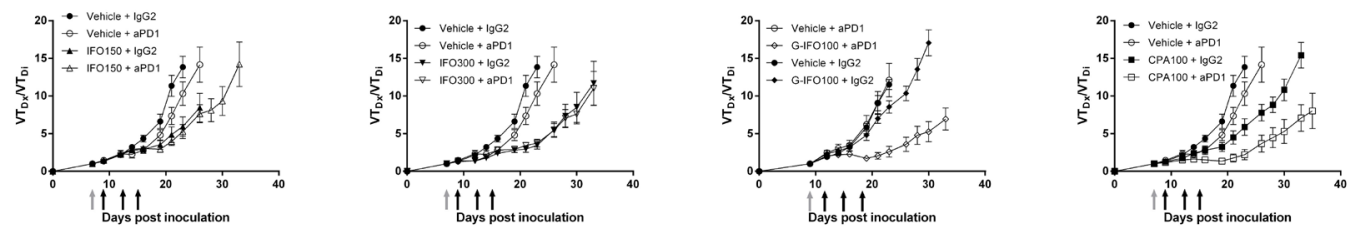

B
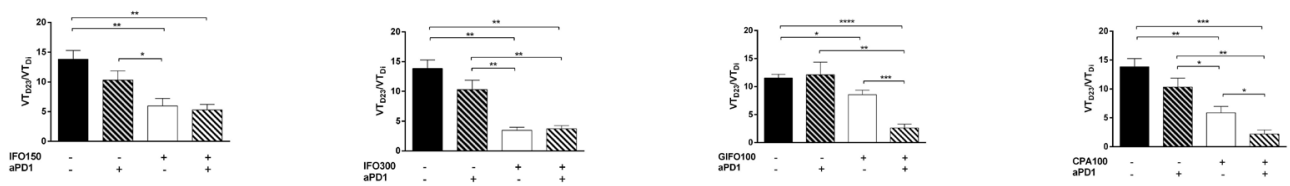

C
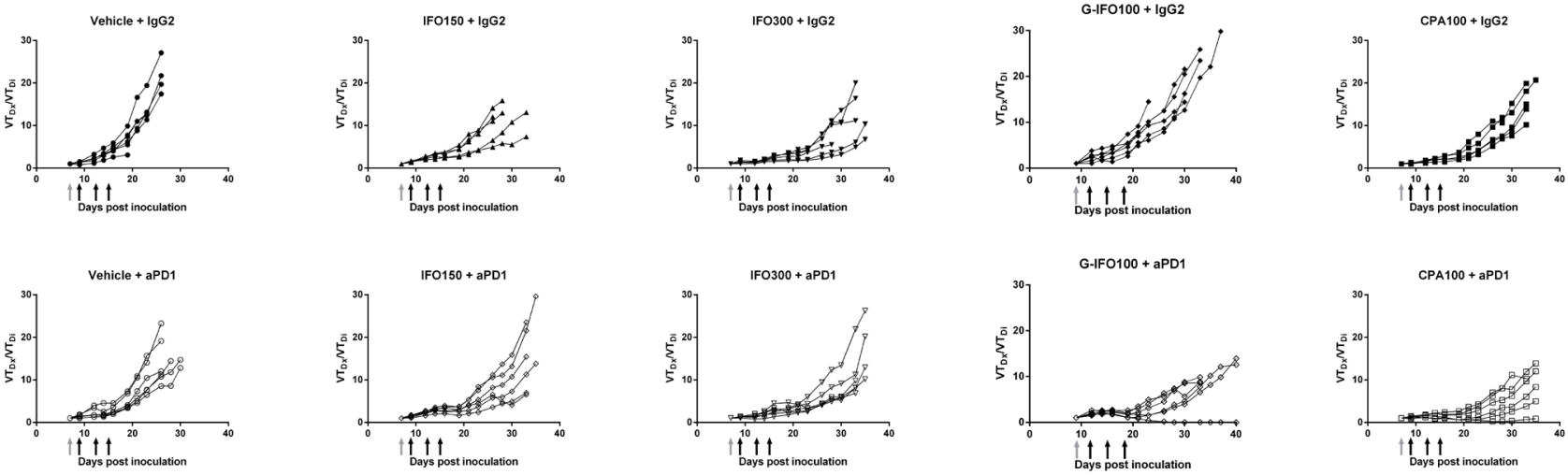

D

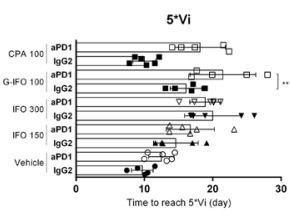

Figure 4 The combination therapy antiprogrammed cell death 1 (PD-1) monoclonal antibodies (mAbs) and geranyloxyifosfamide (G-IFO) induced potent antitumor effect. MCA205 tumor-bearing mice were injected with a single intraperitoneal (i.p.) injection of ifosfamide (IFO) 150 at low dose $(150 \mathrm{mg} / \mathrm{kg})$ or at high dose $(300 \mathrm{mg} / \mathrm{kg})$, G-IFO at low dose (100 mg/kg) or vehicle. Combination with anti-PD-1 mAbs or its isotype control lgG2 has been performed with three i.p. injection at 200 or $250 \mu \mathrm{g} /$ mouse. The gray arrow represents vehicle or chemotherapy injection; the black arrow represents IgG2 or anti-PD-1 injection. Tumor volume was measured every 2-3 days. $\mathrm{VT}_{\mathrm{Dx}}$ correspond to the tumor volume at the day $\mathrm{X}$. Mice were sacrificed when they reached boundary points, as described in the Methods section. (A) Graphs depicted $\mathrm{VT}_{\mathrm{Dx}}$ to $\mathrm{VT}_{\mathrm{Di}}$ ratio $\left(\mathrm{VT}_{\mathrm{Dx}} / \mathrm{VT}_{\mathrm{Di}}\right.$ ) as mean \pm SEM ( $n=6$ mice per group) for groups treated in combination with isotype control lgG2 or anti-PD-1 mAbs. (upper panel) Kinetic tumor growth and (lower panel) $\mathrm{VT}_{\mathrm{D} 23} \mathrm{NT}_{\mathrm{Di}}$ are depicted. Statistical analysis using the two-way analysis of variance test indicated significant differences at $95 \% \mathrm{Cl}$. No adjustment for multiple comparisons was made because of the exploratory component of the analyses. ${ }^{*}, \mathrm{p}<0.05 ;{ }^{* *}, \mathrm{p}<0.01 ;{ }^{* \star *}, \mathrm{p}<0.001 ;{ }^{* * *}, \mathrm{p}<0.0001$. (B) Graphs depicted individual tumor growth in mouse ( $n=6$ mice per group) with treatment in combination with (upper panel) isotype control lgG2 or (lower panel) anti-PD-1 mAbs. (C) Graph depicted time needed to reach five times the initial volume. Median values with IQR are presented. Statistical analysis using Mann-Whitney test indicated significant differences at $95 \% \mathrm{Cl}$. ${ }^{*}, \mathrm{p}<0.05 ;{ }^{* *}, \mathrm{p}<0.01 ;{ }^{* * *}, \mathrm{p}<0.001 ;{ }^{* \star * *}, \mathrm{p}<0.0001$. CPA, cyclophosphamide. 
dose $(150 \mathrm{mg} / \mathrm{kg})$ did not improve the antitumor efficacy of IFO combined to anti-PD-1 mAbs (figure 4A and online supplementary Figure S4D). However, preactivated IFO at low dose (G-IFO eq. $100 \mathrm{mg} / \mathrm{kg}$ ) highly enhanced the antitumor efficacy in combination with anti-PD-1 mAbs (figure 4) and total tumor regressions were observed in $17 \%$ of the mice (figure 4). Finally, reaching five times the initial volume was significantly delayed with G-IFO eq. $100 \mathrm{mg} / \mathrm{kg}+$ anti-PD-1 mAbs compared with G-IFO eq. $100 \mathrm{mg} / \mathrm{kg}$ (figure 4C).

\section{DISCUSSION}

IFO and CPA share a common metabolic pathway; they are prodrugs requiring bioactivation by hepatic enzymes leading to their respective cytotoxic metabolites, isophosphoramide mustard and phosphoramide mustard. Since its introduction in 1958, CPA has been widely used as an antitumor agent, but myelosuppression gives the doselimiting toxicity of CPA. Thereby, CPA is widely used as myeloablative chemotherapy. Myeloablative activity is due to the nornitrogen mustard released from CPA after hepatic metabolization into aldophosphoramide mustard and then enzymatic oxidation into carboxyphosphoramide mustard. ${ }^{4546}$ Note that nornitrogen mustard is also a metabolite of melphalan similarly used as a myeloablative agent. IFO, an isomeric form of CPA, was developed in the early 1970s in order to overcome this myeloablative propriety. Unlike CPA and melphalan, IFO does not release nornitrogen as one of the chloroethyl group is linked to the endocyclic nitrogen while for CPA, both chloroethyl groups are bonded to the exocyclic nitrogen, possibly explaining the absence of myeloablative activity of IFO. ${ }^{35}$ Consequently, for treatment of cancers such as soft-tissue sarcomas, the use of IFO is preferred to $\mathrm{CPA}^{35}$ Difference in toxicity between IFO and CPA may also rely on a different metabolism rate generating threefold to fivefold less of alkylating phosphoramide mustard compared with CPA, ${ }^{46}$ and releasing a majority of CAA which is a nephrotoxic and neurotoxic metabolite. However, the development of preactivated analogs of IFO allowed bypassing hepatic pathway and avoiding CAA release. ${ }^{16}$ Pharmacokinetic study has confirmed the proof of concept of preactivation of IFO; the toxic pathway is bypassed and a higher level of 4-HO-IFO is released.$^{17}$ We confirmed the pharmacokinetic profile of G-IFO (data not shown). As CAA is an unstable metabolite and is released at equimolar quantity with DCE-IFO, we quantified $N^{3}$-DCE-IFO in order to quantify the toxic metabolites encountered on this pathway. As expected, IFO released $N^{\beta}$-DCE-IFO metabolite in plasma whereas G-IFO did not; as $N^{3}$-DCE-IFO is released concomitantly with CAA, we concluded that G-IFO did not release this nephrotoxic and neurotoxic metabolite.

In the present study, we scrutinized immune modifications following i.p. injection of IFO and G-IFO in mice. The $\mathrm{B}$ cell population seemed very affected by oxazaphosphorines even at low dose of IFO $(100 \mathrm{mg} / \mathrm{kg})$ and
G-IFO (eq. $100 \mathrm{mg} / \mathrm{kg}$; data not shown) underlining high sensitivity of B cells to the direct killing by these cytotoxic agents as previously reported. ${ }^{48}$ The presence or absence of tumor does not affect the fate of B cells after IFO or CPA injection. Several studies have previously showed that B cells were preferentially decreased compared with $\mathrm{T}$ cells after CPA treatment; our results brought evidence that IFO is also highly cytotoxic for B cells. B cell sensitivity may rely on the toxic activity of CPA on differentiating B cells compared with thymocytes resulting in a rapid reduction of B cell numbers. ${ }^{49}$ The B cell decrease could be an advantage in the perspective of combination of an oxazaphosphorine with immunotherapy. Immune checkpoint inhibitors such as anti-PD-1, anti-PD-L1 and anti-CTLA-4 antibodies have frequent immune-related adverse events (irAEs). Some of these irAEs are the consequence of autoantibody induction and/or increase. ${ }^{50}$ Nowadays, corticoid administration is the main treatment for serious irAEs with interruption of immunotherapy in most cases. Thus, combining ICBs with oxazaphosphorines could lead to less frequent reactivation of autoreactive B cells and less autoimmune-related adverse events.

We demonstrated the dose-dependent antitumor effect of IFO with an immunomodulatory effect at low doses $(\leq 150 \mathrm{mg} / \mathrm{kg})$ and a cytotoxic effect at higher doses $(>150 \mathrm{mg} / \mathrm{kg})$. Indeed, IFO at low doses did not affect numbers or proportions of splenic $\mathrm{CD}^{+}$and $\mathrm{CD}^{+} \mathrm{T}$ cells in naive and tumor-bearing mice. This immunepharmacodynamic study has shown that IFO at low doses could upregulate the production of IFN $\gamma$, IL-17 and IL-6 after TCR stimulation particularly with IFO $150 \mathrm{mg} / \mathrm{kg}$. At higher doses, no significant or high levels of IFN $\gamma$ and IL-17 were observed consistent with the decrease of splenic T cells. Interestingly, G-IFO at high dose (150 mg/ $\mathrm{kg}$ ) seems to trigger a non-specific splenic and intratumoral $\mathrm{T}$ cells decrease; however, higher secretions of IFN $\gamma$ and IL-6 compared with vehicle were observed. These data highlight a difference of interaction for IFO and G-IFO with $\mathrm{T}$ cells and deserve further investigation.

Interestingly compared with CPA at $100 \mathrm{mg} / \mathrm{kg}$, IFO $150 \mathrm{mg} / \mathrm{kg}$ induced a stronger secretion of IFN $\gamma$, IL-17 and IL-6. IL-6 is known to skew Treg differentiation into non-suppressive proinflammatory Th17 cells $^{5152}$; at $150 \mathrm{mg} / \mathrm{kg}$, the significant correlation between IL-17A and IL-6 secretions (not observed for CPA) suggests that IL-6 could play a role toward Th17 differentiation after low dose-IFO treatment (data not shown). For CPA at $100 \mathrm{mg} / \mathrm{kg}$, Treg differentiation into non-suppressive proinflammatory Th17 cells was not observed ${ }^{30}$ but rather the modification of gut microbiota composition was demonstrated as mandatory for CPA-induced Th17 differentiation. ${ }^{32}$ In our study, no correlation between IL-6 and IL-17A was found after CPA treatment (data not shown), suggesting that Th17 induction might not rely on IL-6-driven Th17 polarization. Although TCR-dependent induction of cytokines was investigated in our study, the precise origin of IL-6 was not clearly determined since we stimulated splenocytes and not purified T cells. IL-6 
is a proinflammatory cytokine produced by several cell types including myeloid cells. As already stated, IFO is less myelotoxic than $\mathrm{CPA}^{35}$; thus, we cannot exclude that higher number of myeloid cells recovered after IFO treatment compared with CPA even at low dose. Myeloid cells are able to secrete large amounts of proinflammatory cytokine such as IL-6 after IFN $\gamma$ triggering ${ }^{53}$ and could explain the higher IL-6 concentrations after IFO treatment compared with CPA, but this is yet to be clearly demonstrated. Regarding preactivated analog of IFO, the IL-6 secretion is proportional to G-IFO's dose with similar secretion between high dose of G-IFO (eq. $150 \mathrm{mg} / \mathrm{kg}$ ) and CPA $100 \mathrm{mg} / \mathrm{kg}$. Interestingly, levels of IL-6 could be of importance since previous observation has suggested that low levels of secreted IL-6 could favor Treg cells while higher amounts of IL- 6 could favor Th17 cell differentiation $^{54}$ as observed with $150 \mathrm{mg} / \mathrm{kg}$ IFO treatment in tumor-bearing mice.

However, one should bear in mind that opposite roles for IFN $\gamma$ and IL-6 have been described particularly in tumor cell proliferation and tumor growth through phosphorylation of STAT1 and STAT3, respectively. The role of the balance between activation of STAT1, considered as antitumoral, and STAT3, considered as protumoral, remains not totally clear. ${ }^{55}$ Consequently, we cannot rule out that higher secretion of IL-6 after IFO $150 \mathrm{mg}$ / $\mathrm{kg}$ could be deleterious compared with CPA $100 \mathrm{mg} / \mathrm{kg}$. Regarding IL-17A, the roles of Th17 cells depend strongly on the context of the ongoing cytokine environment. ${ }^{56}$ IL-17A associated with IFN $\gamma$ production (ie, Th17.1 polarization) might have a better antitumor activity compared with a pure Th17 polarization as suggested after a single injection of low dose of CPA. ${ }^{30} 32$

Many murine syngeneic tumor models could be used to test immune-based therapy and previous data have shown that like in patients with cancer an immune diversity between these tumor models exists and dictates their capacity to respond to immune checkpoints blockers. ${ }^{57}$ MCA205 is known to be poorly sensitive to immunotherapy as tumor cells express low levels of PD-L1 (42-44); we confirmed in this study that MCA205 poorly responds to anti-PD-1 mAbs as a standalone treatment . As shown in figure 4, adding a single injection of G-IFO at eq. $100 \mathrm{mg} / \mathrm{kg}$ or CPA at $100 \mathrm{mg} / \mathrm{kg}$ to anti-PD-1 mAbs treatment improved the antitumor efficacy. The difference in synergy between the immunomodulatory doses of IFO, CPM and G-IFO showed that the synergy with antiPD-1 is not only due to an increase in the level of studied cytokines, that is, INF $\gamma$, IL-17A and IL-6 (non-exhaustive selection). Besides, the treatments causing DNA damage lead to the release of DNA fragments in the cytosol. The interaction of cytosolic DNA with the cGAS protein leads to its activation and the production of cGAMP which will bind to its STING (stimulator of interferon genes) receptor. The CGAS/STING pathway is essential for the antitumor effect of $\mathrm{ICB}^{58}$; therefore, different STING agonists are currently undergoing preclinical evaluation and the rationale for use in combination with ICB for a synergistic antitumour effect has recently been described.$^{59}$ We could hypothesize that phosphoramide or isophosphoramide mustard, released in greater quantities from CPA and G-IFO compared with IFO, is responsible for cGAS/STING activation. This would favor Th1 adaptive immune response as shown with IFN $\gamma$ secretion where CPA and G-IFO induced systematically more IFN $\gamma$ than IFO. Interestingly, a potent synergy was observed with anti-PD-1 mAbs associated with G-IFO eq. $100 \mathrm{mg}$ / $\mathrm{kg}$. Thus, G-IFO at low dose seemed pertinent to leverage anti-PD-1 mAbs activity. Previous studies have shown that some chemotherapy such as gemcitabine and paclitaxel increase the expression of PD-L1 on the surface of tumor cells. ${ }^{60}$ IFN $\gamma$ and IL-6 cytokines upregulate PD-L1 expression on solid tumor cells through JAK-signal transcription pathway $^{6162}$; thus, G-IFO through adaptive T cell immunity modulation could also increase PD-L1 expression on tumor cells. This hypothesis remains to be explored. This study provided proof of concept on the synergy between anti-PD-1 and a new alkylating agent. As reported by Wu and Waxman reviewing works dealing with immunogenic chemotherapy, both dose and schedule are major parameters for a significant efficacy of the synergy. ${ }^{63}$ The authors show the huge number of combination strategies dealing with the dose of the chemotherapy (low, medium or high dose the number of repeated injections), the number of injections of the immunotherapy and the number of days between chemotherapy and immunotherapy. Indeed, there are multiple strategies that give multiple events, such as changes in the tumor-tolerant immune cells, chemotherapy treatment-induced drug cytotoxicity, lymphopenia or immune-stimulatory signals. We think that finding the optimal combination between IFO/G-IFO and anti-PD-1 could have taken many months of experimentation. Further studies are needed to find the optimal combination between IFO/G-IFO and antiPD-1 including the dose, the frequency of the anti-PD-1 administrations, in the context of future clinical trials, knowing that transpose the results from murine models to human is not obvious.

The aim of the design of novel oxazaphosphorine was to optimize the metabolic balance while improving biodistribution through the terpenyl modification. In addition, as reported for others chemotherapeutic agents, immunogenic death or immunomodulation is linked to the dose. Gemcitabine used at $120 \mathrm{mg} / \mathrm{kg}$ in mouse model (a dose similar to the equivalent dose used in patients) selectively reduces the numbers of myeloid suppressor cells while preserving $\mathrm{CD} 4^{+} \mathrm{T}$ cells, $\mathrm{CD} 8^{+} \mathrm{T}$ cells and $\mathrm{B}$ cells ${ }^{64}$ whereas CPA is used at low doses for their immunomodulatory effects. G-IFO was investigated for its capability to deliver 4-HO-IFO in the same proportion as CPA. To generate immunomodulation effects and not lymphopenic effets, G-IFO, as others alkylating agents need to be used at low doses, especially in combination with ICB. Numerous clinical trials are currently studying CPA for its immunomodulatory properties, in combination with antitumor immunotherapy (vaccination and ICBs): 172 
ongoing studies including 25 that study the association of low-dose CPA with anti-PD-1 (clinicaltrials.gov). G-IFO was investigated for its capability to deliver 4-HO-IFO in the same proportion as CPA. To generate immunomodulation effects and not lymphopenic effets, G-IFO as others alkylating agents need to be used at low doses, especially in combination with ICB.

Altogether, this study showed the importance of oxazaphosphorine's metabolism and the well-balanced administered doses that favor $\mathrm{T}$ cell activation rather than lymphopenia and that G-IFO could be a promising chemotherapeutic agent candidate for combination with immunotherapy.

\section{Author affiliations}

${ }^{1}$ Molecular Radiotherapy and Innovative Therapeutics, Unité Mixte de Recherche 1030 INSERM, Gustave Roussy, F-94805, Villejuif, France

${ }^{2}$ Vectorology and Anticancer Therapies, Unité Mixte de Recherche 8203 Centre National de la Recherche Scientifique, Gustave Roussy, F-94805, Villejuif, France ${ }^{3}$ Laboratoire d'immunomonitoring En Oncologie, Gustave Roussy, F-94805, Villejuif, France

${ }^{4}$ Laboratory of Genetic Instability and Oncogenesis, Unité Mixte de Recherche 8200 Centre National de la Recherche Scientifique, Gustave Roussy Institute, F-94805, Villejuif, France

${ }^{5}$ Faculté de Pharmacie, Université Paris-Saclay, F-92296, Chatenay-Malabry, France ${ }^{6}$ Pharmacology Department, Gustave Roussy, Villejuif, France

Acknowledgements The authors thank Patrick Gonin from the PlatForm for Preclinical Evaluation. The authors thank Stella Ghouti-Baxter for proofreading and corrections of English grammar and syntax.

Contributors JD did the experiments and wrote the article. CS and MD contributed to the experiments. NC-G and AP managed the experiments and corrected the article. J-LP read and corrected the article.

Funding This study was funded by Gustave Roussy Cancer Campus, Fondation Gustave Roussy, the Institut national de la santé et de la recherche médicale, the Centre national de la recherche scientifique, SIRIC SOCRATE (INCa DGOS INSERM 6043), SIRIC SOCRATE 2.0 (INCa-DGOS-INSERM_12551) and MM0 program: ANR-10IBHU-0001).

Competing interests None declared.

Patient consent for publication Not required.

Provenance and peer review Not commissioned; externally peer reviewed.

Data availability statement Data are available upon reasonable request. Not applicable.

Open access This is an open access article distributed in accordance with the Creative Commons Attribution Non Commercial (CC BY-NC 4.0) license, which permits others to distribute, remix, adapt, build upon this work non-commercially, and license their derivative works on different terms, provided the original work is properly cited, appropriate credit is given, any changes made indicated, and the use is non-commercial. See http://creativecommons.org/licenses/by-nc/4.0/.

\section{ORCID iD}

Julia Delahousse http://orcid.org/0000-0002-2346-9608

\section{REFERENCES}

1 Lee $\mathrm{SH}$, Chang $\mathrm{MH}$, Baek KK, et al. High-Dose ifosfamide as second- or third-line chemotherapy in refractory bone and soft tissue sarcoma patients. Oncology 2011;80:257-61.

2 Nielsen OS, Judson I, van Hoesel Q, et al. Effect of high-dose ifosfamide in advanced soft tissue sarcomas. A multicentre phase II study of the EORTC soft tissue and bone sarcoma group. Eur J Cancer 2000;36:61-7.

3 Budach W, Budach V, Stuschke M, et al. Efficacy of ifosfamide, dacarbazine, doxorubicin and cisplatin in human sarcoma xenografts. Br J Cancer 1994;70:29-34.
4 Ettinger DS, Lagakos S. Phase III study of CCNU, cyclophosphamide, adriamycin, vincristine, and VP-16 in small-cell carcinoma of the lung. Cancer 1982;49:1544-54.

5 Livingston RB, Einhorn LH, Bodey GP, et al. Comb (cyclophosphamide, Oncovin, methyl-CCNU, and bleomycin): a fourdrug combination in solid tumors. Cancer 1975;36:327-32.

6 Salman H, Perez A, Sparano JA, et al. Phase II Trial of Infusional Cyclophosphamide, Idarubicin, and Etoposide in Poor Prognosis Non-Hodgkin's Lymphoma. Am J Clin Oncol 2003;26:338-43.

7 Avery TL, Roberts D. Adriamycin and cyclophosphamide in combination chemotherapy of L1210 leukemia. Cancer Res 1977;37:678-83.

8 Carmel RJ, Brown JM. The effect of cyclophosphamide and other drugs on the incidence of pulmonary metastases in mice. Cancer Res 1977:37:145-51.

9 Kanno TYN, Sensiate LA, Paula NAde, et al. Toxic effects of different doses of cyclophosphamide on the reproductive parameters of male mice. Brazilian Journal of Pharmaceutical Sciences 2009;45:313-9.

10 Goren MP, Wright RK, Pratt CB, et al. Dechloroethylation of ifosfamide and neurotoxicity. Lancet 1986;2:1219-20.

11 Ben Abid F, Gazzah A, Ousbane A, et al. Les alkylants. Oncologie 2007;9:751-7.

12 Kerbusch T, de Kraker J, Keizer HJ, et al. Clinical pharmacokinetics and pharmacodynamics of ifosfamide and its metabolites. Clin Pharmacokinet 2001;40:41-62.

13 Le Cesne A, Antoine E, Spielmann M, et al. High-Dose ifosfamide: circumvention of resistance to standard-dose ifosfamide in advanced soft tissue sarcomas. J Clin Oncol 1995;13:1600-8.

14 Skinner R, Cotterill SJ, Stevens MC. Risk factors for nephrotoxicity after ifosfamide treatment in children: a UKCCSG late effects group study. United Kingdom children's cancer Study Group. Br J Cancer 2000;82:1636-45.

15 Berrak SG, Pearson M, Berberoğlu S, et al. High-Dose ifosfamide in relapsed pediatric osteosarcoma: therapeutic effects and renal toxicity. Pediatr Blood Cancer 2005;44:215-9.

16 Skarbek C, Lesueur LL, Chapuis H, et al. Preactivated oxazaphosphorines designed for isophosphoramide mustard delivery as bulk form or nanoassemblies: synthesis and proof of concept. $J$ Med Chem 2015;58:705-17

17 Skarbek C, Delahousse J, Pioche-Durieu C, et al. Poly-isoprenylated ifosfamide analogs: preactivated antitumor agents as free formulation or nanoassemblies. Int J Pharm 2017;532:748-56.

$18 \mathrm{Li} \mathrm{H}$, Fan X, Houghton J. Tumor microenvironment: the role of the tumor stroma in cancer. J Cell Biochem 2007;101:805-15.

19 Hodi FS, O'Day SJ, McDermott DF, et al. Improved survival with ipilimumab in patients with metastatic melanoma. $N$ Engl $J$ Med 2010;363:711-23.

20 Zielinski C, Knapp S, Mascaux C, et al. Rationale for targeting the immune system through checkpoint molecule blockade in the treatment of non-small-cell lung cancer. Ann Oncol 2013;24:1170-9.

21 Proietti E, Moschella F, Capone I, et al. Exploitation of the propulsive force of chemotherapy for improving the response to cancer immunotherapy. Mol Oncol 2012;6:1-14

22 Chen G, Emens LA. Chemoimmunotherapy: reengineering tumor immunity. Cancer Immunol Immunother 2013;62:203-16.

23 Bracci L, Schiavoni G, Sistigu A, et al. Immune-Based mechanisms of cytotoxic chemotherapy: implications for the design of novel and rationale-based combined treatments against cancer. Cell Death Differ 2014;21:15-25.

24 Taieb J, Chaput N, Schartz N, et al. Chemoimmunotherapy of tumors: cyclophosphamide synergizes with exosome based vaccines. J Immunol 2006;176:2722-9.

25 Ghiringhelli F, Larmonier N, Schmitt E, et al. Cd4+Cd25+ regulatory $T$ cells suppress tumor immunity but are sensitive to cyclophosphamide which allows immunotherapy of established tumors to be curative. Eur J Immunol 2004;34:336-44.

26 Lutsiak MEC, Semnani RT, De Pascalis R, et al. Inhibition of CD4(+)25+ T regulatory cell function implicated in enhanced immune response by low-dose cyclophosphamide. Blood 2005;105:2862-8.

27 Loyher P-L, Rochefort J, Baudesson de Chanville C, et al. Ccr2 influences $T$ regulatory cell migration to tumors and serves as a biomarker of cyclophosphamide sensitivity. Cancer Res 2016;76:6483-94.

28 Traverso I, Fenoglio D, Negrini S, et al. Cyclophosphamide inhibits the generation and function of CD8(+) regulatory T cells. Hum Immunol 2012;73:207-13.

29 Ge Y, Domschke C, Stoiber N, et al. Metronomic cyclophosphamide treatment in metastasized breast cancer patients: immunological effects and clinical outcome. Cancer Immunol Immunother 2012:61:353-62. 
30 Viaud S, Flament C, Zoubir M, et al. Cyclophosphamide induces differentiation of Th17 cells in cancer patients. Cancer Res 2011;71:661-5.

31 Salem ML, Kadima AN, El-Naggar SA, et al. Defining the ability of cyclophosphamide preconditioning to enhance the antigen-specific CD8+ T-cell response to peptide vaccination: creation of a beneficial host microenvironment involving type I IFNs and myeloid cells. $J$ Immunother 2007;30:40-53.

32 Viaud S, Saccheri F, Mignot G, et al. The intestinal microbiota modulates the anticancer immune effects of cyclophosphamide. Science 2013;342:971-6.

33 Schiavoni G, Sistigu A, Valentini M, et al. Cyclophosphamide synergizes with type I interferons through systemic dendritic cell reactivation and induction of immunogenic tumor apoptosis. Cancer Res 2011;71:768-78.

34 Pfirschke C, Engblom C, Rickelt S, et al. Immunogenic chemotherapy sensitizes tumors to checkpoint blockade therapy. Immunity 2016;44:343-54.

35 Bramwell VH, Mouridsen HT, Santoro A, et al. Cyclophosphamide versus ifosfamide: final report of a randomized phase II trial in adult soft tissue sarcomas. Eur J Cancer Clin Oncol 1987;23:311-21.

36 Le Deley M-C, Paulussen M, Lewis I, et al. Cyclophosphamide compared with ifosfamide in consolidation treatment of standard-risk Ewing sarcoma: results of the randomized noninferiority EuroEWING99-R1 trial. J Clin Oncol 2014;32:2440-8.

37 Vela-Ojeda J, Tripp-Villanueva F, Montiel-Cervantes L, et al. Prospective randomized clinical trial comparing high-dose ifosfamide + GM-CSF vs high-dose cyclophosphamide + GM-CSF for blood progenitor cell mobilization. Bone Marrow Transplant 2000;25:1141-6.

38 Lind MJ, McGown AT, Hadfield JA, et al. The effect of ifosfamide and its metabolites on intracellular glutathione levels in vitro and in vivo. Biochem Pharmacol 1989;38:1835-40.

39 Issels RD, Meier TH, Müller E, et al. Ifosfamide induced stress response in human lymphocytes. Mol Aspects Med 1993;14:281-6.

40 Multhoff G, Meier T, Botzler C, et al. Differential effects of ifosfamide on the capacity of cytotoxic T lymphocytes and natural killer cells to lysE their target cells correlate with intracellular glutathione levels. Blood 1995;85:2124-31.

41 Kuppner MC, Bleifuss E, Noessner E, et al. Differential effects of ifosfamide on dendritic cell-mediated stimulation of T cell interleukin-2 production, natural killer cell cytotoxicity and interferongamma production. Clin Exp Immunol 2008;153:429-38.

42 Rios-Doria J, Durham N, Wetzel L, et al. Doxil synergizes with cancer immunotherapies to enhance antitumor responses in syngeneic mouse models. Neoplasia 2015;17:661-70.

43 Wei S, Shreiner AB, Takeshita N, et al. Tumor-Induced immune suppression of in vivo effector T-cell priming is mediated by the B7-H1/PD-1 axis and transforming growth factor beta. Cancer Res 2008;68:5432-8.

44 Fallon JK, Vandeveer AJ, Schlom J, et al. Enhanced antitumor effects by combining an IL-12/anti-DNA fusion protein with avelumab, an anti-PD-L1 antibody. Oncotarget 2017;8:20558-71.

45 Juma FD, Rogers HJ, Trounce JR. The pharmacokinetics of cyclophosphamide, phosphoramide mustard and nor-nitrogen mustard studied by gas chromatography in patients receiving cyclophosphamide therapy. Br J Clin Pharmacol 1980;10:327-35.

46 Fleming RA. An overview of cyclophosphamide and ifosfamide pharmacology. Pharmacotherapy 1997;17:146S-54.
47 Giraud B, Hebert G, Deroussent A, et al. Oxazaphosphorines: new therapeutic strategies for an old class of drugs. Expert Opin Drug Metab Toxicol 2010;6:919-38.

48 Stockman GD, Heim LR, South MA, et al. Differential effects of cyclophosphamide on the $\mathrm{B}$ and $\mathrm{T}$ cell compartments of adult mice. $\mathrm{J}$ Immunol 1973;110:277-82.

49 Hemendinger RA, Bloom SE. Selective mitomycin C and cyclophosphamide induction of apoptosis in differentiating B lymphocytes compared to T lymphocytes in vivo. Immunopharmacology 1996;35:71-82.

50 Menzies AM, Johnson DB, Ramanujam S, et al. Anti-Pd-1 therapy in patients with advanced melanoma and preexisting autoimmune disorders or major toxicity with ipilimumab. Ann Oncol 2017;28:368-76.

51 Komatsu N, Okamoto K, Sawa S, et al. Pathogenic conversion of Foxp3+ T cells into Th17 cells in autoimmune arthritis. Nat Med 2014;20:62-8.

52 Sharma MD, Hou D-Y, Liu Y, et al. Indoleamine 2,3-dioxygenase controls conversion of Foxp3+ Tregs to TH17-like cells in tumordraining lymph nodes. Blood 2009;113:6102-11.

53 Sanceau J, Wijdenes J, Revel M, et al. IL-6 and IL-6 receptor modulation by IFN-gamma and tumor necrosis factor-alpha in human monocytic cell line (THP-1). Priming effect of IFN-gamma. J Immunol 1991;147:2630-7.

54 Stevanin M, Busso N, Chobaz V, et al. CD11b regulates the Treg/Th17 balance in murine arthritis via IL-6. Eur J Immunol 2017;47:637-45.

55 Regis G, Pensa S, Boselli D, et al. Ups and downs: the STAT1:STAT3 seesaw of Interferon and gp130 receptor signalling. Semin Cell Dev Biol 2008;19:351-9.

56 Wilke CM, Kryczek I, Wei S, et al. Th17 cells in cancer: help or hindrance? Carcinogenesis 2011;32:643-9.

57 Mosely SIS, Prime JE, Sainson RCA, et al. Rational selection of syngeneic preclinical tumor models for immunotherapeutic drug discovery. Cancer Immunol Res 2017;5:29-41.

58 Wang $\mathrm{H}$, Hu S, Chen X, et al. cGAS is essential for the antitumor effect of immune checkpoint blockade. Proc Natl Acad Sci U S A 2017;114:1637-42.

59 Li A, Yi M, Qin S, et al. Activating cGAS-STING pathway for the optimal effect of cancer immunotherapy. J Hematol Oncol 2019;12:35.

60 Peng J, Hamanishi J, Matsumura N, et al. Chemotherapy induces programmed cell Death-Ligand 1 overexpression via the nuclear factor- $\mathrm{\kappa} B$ to foster an immunosuppressive tumor microenvironment in ovarian cancer. Cancer Res 2015;75:5034-45.

61 Mimura $\mathrm{K}$, Teh $\mathrm{JL}$, Okayama $\mathrm{H}$, et al. Pd-L1 expression is mainly regulated by interferon gamma associated with JAK-STAT pathway in gastric cancer. Cancer Sci 2018;109:43-53.

62 Zhang N, Zeng Y, Du W, et al. The EGFR pathway is involved in the regulation of PD-L1 expression via the IL-6/JAK/STAT3 signaling pathway in EGFR-mutated non-small cell lung cancer. Int $J$ Oncol 2016;49:1360-8.

$63 \mathrm{Wu}$ J, Waxman DJ. Immunogenic chemotherapy: dose and schedule dependence and combination with immunotherapy. Cancer Lett 2018;419:210-21.

64 Suzuki E, Kapoor V, Jassar AS, et al. Gemcitabine selectively eliminates splenic Gr-1+/CD11b+ myeloid suppressor cells in tumor-bearing animals and enhances antitumor immune activity. Clin Cancer Res 2005;11:6713-21. 